\title{
Three Dimensional Conformal Radiotherapy and Androgen Deprivation Therapy in Patients with Clinically Localized Prostate Cancer; Hacettepe University Experience
}

\author{
Yurday OZDEMIR ${ }^{1,2}$, Fadil AKYOL ${ }^{1}$, Gokhan OZYIGIT ${ }^{1}$, Pervin HURMUZ, \\ Cem ONAL ${ }^{2}$, Ugur SELEK ${ }^{3}$, Erdem KARABULUT ${ }^{4}$

\footnotetext{
${ }^{1}$ Hacettepe University Faculty of Medicine, Department of Radiation Oncology, Ankara

${ }^{2}$ Başkent University Faculty of Medicine, Department of Radiation Oncology, Adana

${ }^{3}$ Koç University Faculty of Medicine, Department of Radiation Oncology, İstanbul
} \\ ${ }^{4}$ Hacettepe University Faculty of Medicine, Department of Biostatistics, Ankara, TURKEY
}

\begin{abstract}
The aim of this study is to evaluate the treatment results of three dimensional conformal radiotherapy (3DCRT) and androgen deprivation therapy (ADT) in patients with clinically localized prostate cancer (CLPC). Between June 1998 and December 2011, 577 patients with the diagnosis of CLPC were treated. ADT was started 3 months prior to radiotherapy (RT). 3DCRT was delivered to prostate and the seminal vesicles (SV) to a total dose of 70Gy. Additionally, patients with lymph node (LN) positivity received $50.4 \mathrm{~Gy}$ RT to pelvic LN's. Median follow up time was 65 months. Five-ten years overall survival (OS), cause specific survival (CSS), PSA relapse-free survival (PSA-RFS) and distant metastasis-free survival (DMFS) rates were 92-74\%, 97-91\%, 77-55\% and 94-88\%, respectively. OS was negatively affected from LN positivity $(p<0.001)$. In the subgroup of patients with GS $\geq 8$, there was no significant difference between $<1$ years and $\geq 1$ years of ADT in terms of CSS, PSA-RFS and DMFS. OS was better in patients with $<1$ years of ADT $(p=0.01)$. Five year OS $(p=0.02)$, CSS $(p=0.05)$, PSA-RFS $(p=0.01)$ and DMFS $(p=0.07)$ rates were inferior in the high risk group patients that used ADT $\geq 1$ year. Acute and late RTOG grade III/IV gastrointestinal system toxicity rates were $1.7 \%$ and 5\% and acute and chronic RTOG grade III/IV genitourinary system toxicity rates were $1.4 \%$ and $5 \%$, respectively. 3DCRT and ADT combination is an effective treatment modality with acceptable toxicities in patients with clinically localized prostate cancer.
\end{abstract}

Keywords: Prostate cancer, Conformal radiotherapy, Androgen deprivation therapy

ÖZET

Lokalize Prostat Kanserli Olgularda Üç Boyutlu Konformal Radyoterapi ve Total Androjen Blokajı; Hacettepe Üniversitesi Deneyimi

Bu çalışmanın amacı, üç boyutlu konformal radyoterapi (3BKRT) ve total androjen blokajı (TAB) Lokalize prostat kanserli olgularımızdaki tedavi sonuçlarımızı değerlendirmek. Haziran 1998 ve Aralık 2011 tarihleri arasında lokalize prostat kanseri tanısıyla 577 olgu tedavi edildi. TAB tedavisine radyoterapiden (RT) 3 ay sonar başlandı. 3BKRT olarak prostat ve seminal veziküllere toplam 70 Gy uygulandı. Ek olarak lenf nodu (LN) tutulumu olan olgularda pelvic LN'larına 50.4 Gy uygulandı. Ortanca izlem süresi 65 aydır. Beş-on yıllık genel sağkalım (GS), hastalı̆̆a özgü sağkalım (HSS), PSA-relapssız sağkalım (PSA-RFS) ve uzak metastazsız sağkalım (DMFS) oranları sırasıly \%92-74, \%97-91, \%77-55 ve \%94-88 bulundu. LN tutulumu GS'ı olumsuz etkilemiştir ( $p<0.001$ ). Gleason skoru $\geq 8$ olan olgularda $<1$ yıl ile $\geq 1$ yıl TAB kullanımı arasında HSS, PSA-RFS ve DMFS açııından fark yoktu. Ancak $<1$ yıl TAB kullananlarda GS daha iyiydi $(p=0.01)$. Yüksek riskli grupta olup $\geq 1$ yıl TAB kullanan hastalarda 5 ylllık GS $(p=0.02), H S S(p=0.05), P S A-R F S(p=0.01)$ ve DMFS $(p=0.07$ ) daha düşük bulundu. Erken ve geç dönem RTOG grad III/IV gastrointestinal sistem toksisite oranları \%1.7 ve \%5 bulundu. Erken ve geç dönem RTOG grad III/IV genitoüriner sistem toksisite oranları \%1.4 ve \%5 bulundu. Lokalize prostat kanseri tedavisinde 3BKRT ve TAB tedavisi etkili ve güvenli bir tedavi biçimidir.

Anahtar Kelimeler: Prostat kanseri, Konformal radyoterapi, Androjen deprivasyon tedavisi 


\section{INTRODUCTION}

Treatment options for patients with clinically localized prostate cancer include active surveillance, radical prostatectomy or radiotherapy (RT) with or without androgen deprivation treatment (ADT). The treatment decision is made according to risk group of the patient. Although there is no randomized study comparing RT with surgery various studies demonstrated that RT is equally effective with surgery in the treatment of clinically localized prostate cancer. Its effect improves when the dose delivered to target is increased. Three dimensional conformal radiotherapy (3DCRT) techniques provide the delivery of higher doses to the target while sparing the adjacent normal structures. Additionally, RT and ADT have been shown to improve overall survival (OS), PSA relapse free survival (PSA-RFS) and distant metastasis free survival (DMFS) $)^{1-3}$ compared to RT alone. Thus RT with ADT is the standard of care for localized prostate cancer in intermediate and high risk patients.

In this study we aimed to evaluate our treatment results in patients with clinically localized prostate cancer and identify the factors that had might affect the prognosis of the patients.

\section{PATIENTS AND METHODS}

Between June 1998 and June 2011, 577 patients with the diagnosis of clinically localized prostate adenocarcinoma were treated according to our institutional treatment protocol. ADT consisted of LHRH analogue plus antiandrogen. ADT was started 3 months prior to RT and was continued according to the D'Amico risk group of the patient at the initial diagnosis. The work up studies included initial PSA (iPSA), Gleason Score (GS), transrectal USG or prostat MRI, abdominopelvic computerized tomography (CT) and Tc- $99 \mathrm{~m}$ bone scintigraphy.

Clinical target volume was defined as the prostate gland and the entire seminal vesicles (SV). Total dose of $70 \mathrm{~Gy}$ was delivered to $95 \%$ isodose. Thus, the dose at the International Commission of Radiation Units and Measurement (ICRU) point was 73.6 Gy. Twenty nine patients with LN positivity received RT to pelvis (50.4 Gy) plus prostate and
SV (70 Gy). ADT was used $\geq 1$ year in $38 \%$ of the patients. We used 7 fields to deliver the dose to the prostate and SV. The doses for adjacent normal structures were kept below the tolerance limits of each organ; $\mathrm{V} 70<35 \%$ and $\mathrm{V} 40<50 \%$ for bladder, $\mathrm{V} 70<20 \%$ and $\mathrm{V} 40<40 \%$ for rectum, and $\mathrm{V} 50<5 \%$ for femoral heads.

The patients were followed up every 3 months for the first 2 years, every 6 months for the next 3 years and annually thereafter. Follow up included routine physical examination, hemogram, liver function tests, PSA and transrectal USG.

OS, prostate cancer specific survival (CSS), PSARFS, DMFS were assessed in relation to GS (GS 2-6, GS 7, GS 8-10), iPSA (PSA $\leq 10,10<\mathrm{PSA} \leq$ 20, PSA $>20$ ), total percentage of cancer containing cores (TPC), percent of positive cores (PPC) (and perineural invasion (PNI) status. TPC was defined as the division of total tumor percentage of cancer containing cores with number of total cores, multiplied by 100. PPC was defined as the number of biopsy cores with cancer cells divided by the total number of cores, multiplied by $100 .{ }^{4}$ The patients were grouped as TPC $<\% 50$ or $\geq \% 50$ and PPC $\leq \% 50$ or $>\% 50$. PNI was defined as the presence of prostate cancer cells within the spaces along the prostatic nerves. ${ }^{5}$ Patients with T1-2a and PSA $\leq 10 \mathrm{ng} / \mathrm{ml}$ and GS 2-6 were categorized as low risk, T2b and $10<$ PSA $\leq 20$ and GS 7 as intermediate risk and T2c-T4 or PSA $>20 \mathrm{ng} / \mathrm{ml}$ and GS 8-10 as high risk groups according to D'Amico classification. ${ }^{6}$ Acute and late treatment related toxicities were also evaluated using RTOG Acute Radiation Morbidity Scoring Criteria and RTOG/ EORTC Late Radiation Morbidity Scoring Schema.

\section{Statistics}

SPSS 16.0 (SPSS Inc., Chicago, IL) version was used for the statistical analysis. The value of $\mathrm{p}<$ 0.05 was used to determine statistical significance. Time to last follow-up, biochemical failure and distant metastases were calculated starting from the final date of 3DCRT. Kaplan-Meier test was used to estimate all survival probabilities and hazard rates. Evaluation of prognostic factors was done by Logrank test for univariate analysis and Cox regression for multivariate analysis. 


\section{RESULTS}

Median follow up time was 65 months (range, 3-169 months). There were 29 patients with lymph node (LN) involvement and 8 of them had pathological confirmation of $\mathrm{LN}$ positivity. The characteristics of the patients were summarized in Table 1. PNI status was reported in $520(90 \%)$ patients and it was positive in $36.5 \%$ of the cases. PPC and TPC status were reported in $445(77 \%)$ and $428(74 \%)$ patients, respectively. The percentage of patients with PPC $>50 \%$ was $40 \%$ and TPC $\geq$ $50 \%$ was $25.5 \%$. The characteristics of patients according to PPC and TPC status were listed in Table 2. Both high PPC and TPC were correlated with higher PSA, GS, clinical T stage, higher risk group, PNI positivity and increased ADT duration $(\mathrm{p}<$ 0.001). Patients with $\mathrm{PPC}>\% 50$ and $\mathrm{TPC} \geq \% 50$ were tended to be younger than patients with PPC $\leq \% 50$ and $\mathrm{TPC}<\% 50(\mathrm{p}<0.004$ and $\mathrm{p}<0.001$, respectively). PNI positivity didn't correlate with patient age $(\mathrm{p}=0.28)$.

\section{Overall Survival}

Five and 10 years OS rates for entire cohort were $92 \%$ and $74 \%$ respectively. According to T stage of the patients, there was no difference in OS. Five and 7 year OS rates in $\mathrm{LN}(+)$ and $\mathrm{LN}(-)$ groups were 69 and 55\% and 97 and 92\%, respectively (p< 0.001 ). When the patients were analyzed according to the GS groups, 5-10 year OS rates were 93 and $82 \%$ in GS $\leq 6$ group; 95 and $72 \%$ in GS 7 group. The patients with GS $\geq 8$ had 5 and 10 year OS rates of 87 and $59 \%$ that were significantly lower than $\mathrm{GS} \leq 6(\mathrm{p}=0.008)$ and GS $7(\mathrm{p}=0.027)$ groups. There was no significant difference in OS between $\mathrm{GS} \leq 6$ and GS 7 patient groups $(\mathrm{p}=0.89)$. Five and 10 year OS rates in the PSA $\leq 10 \mathrm{ng} / \mathrm{ml}$, PSA $10-20 \mathrm{ng} / \mathrm{ml}$ and PSA $>20 \mathrm{ng} / \mathrm{ml}$ groups were 95 and $84 \%, 87$ and 69\%, 91 and 65\%, respectively. OS rates in the PSA $\leq 10 \mathrm{ng} / \mathrm{ml}$ group were significantly higher than PSA $10-20 \mathrm{ng} / \mathrm{ml}(\mathrm{p}=0.002)$ and PSA $>20 \mathrm{ng} / \mathrm{ml}$ groups $(\mathrm{p}=0.008)$. However there was no difference in OS between the latter two groups $(p=0.64)$. OS rates in low risk patients were higher than intermediate $(\mathrm{p}=0.005)$ and high risk patients $(\mathrm{p}=0.002)$. PNI $(+)$ patients had 5-10 year OS rates of 89 and $60 \%$ compared to 94 and

\begin{tabular}{|c|c|}
\hline Patient characteristics & Number (\%) \\
\hline Median Age (range) & 68 years ( $41-87$ years) \\
\hline \multicolumn{2}{|l|}{ iPSA $(\Omega)$} \\
\hline$\leq 10(\mathrm{ng} / \mathrm{ml})$ & $209(36.2)$ \\
\hline $10-20(\mathrm{ng} / \mathrm{ml})$ & $158(27.4)$ \\
\hline$>20(\mathrm{ng} / \mathrm{ml})$ & 189 (32.8) \\
\hline \multicolumn{2}{|l|}{ Gleason Score $(\Omega)$} \\
\hline$\leq 6$ & $245(42)$ \\
\hline 7 & $166(29)$ \\
\hline$\geq 8$ & $166(29)$ \\
\hline \multicolumn{2}{|l|}{ Clinical T stage $(\Omega)$} \\
\hline $\mathrm{T} 1-\mathrm{T} 2 \mathrm{a}$ & $285(49)$ \\
\hline T2b & $46(8)$ \\
\hline T2c-T4 & $238(41)$ \\
\hline \multicolumn{2}{|l|}{$\mathrm{PNI}$ status $(\Omega)$} \\
\hline $\mathrm{PNI}(+)$ & $211(36.5)$ \\
\hline PNI (-) & $309(53.5)$ \\
\hline \multicolumn{2}{|l|}{$\operatorname{PPC}$ status $(\Omega)$} \\
\hline $\mathrm{PPC} \leq 50 \%$ & 216(37) \\
\hline PPC > 50\% & $229(40)$ \\
\hline \multicolumn{2}{|l|}{ TPC status $(\Omega)$} \\
\hline $\mathrm{TPC}<50 \%$ & $280(48.5)$ \\
\hline TPC $\geq 50 \%$ & $148(25.5)$ \\
\hline \multicolumn{2}{|l|}{ D'Amico Risk Group $(\Omega)$} \\
\hline Low & $97(16.8)$ \\
\hline Intermediate & $118(20.5)$ \\
\hline High & 359 (62.2) \\
\hline ADT < 1 year $(\Omega)$ & $311(54)$ \\
\hline $\mathrm{ADT} \geq 1$ year & 218 (38) \\
\hline \multicolumn{2}{|c|}{$\begin{array}{l}\text { Abbreviations: } \mathrm{PPC}=\text { percent of tumor positive cores } \\
\text { TPC=total percentage of cancer containing cores; iPSA= } \\
\text { initial prostate specific antigen; PNI= perineural invasion } \\
\text { ADT= androgen deprivation therapy; }(\Omega)=\text { Not available in } \\
\text { all patients due to missing data }\end{array}$} \\
\hline
\end{tabular}

$79 \%$ in PNI (-) patients ( $\mathrm{p}=0.06)$. Presence of TPC $\geq 50 \%$ and PPC $>50 \%$ were not a predictor for OS $(\mathrm{p}=0.9$ and $\mathrm{p}=0.1$, respectively). In the multivariate analyses only LN positivity significantly decreased OS $(\mathrm{p}=0.01)$.

\section{Prostate Cancer Specific Survival}

Twenty four patients died because of prostate cancer. CSS at 5 and 10 years were $97 \%$ and $91 \%$. On univariate analysis, CSS rates in T2c-T3b groups were worse than $\mathrm{T} 1-\mathrm{T} 2 \mathrm{a}$ groups $(\mathrm{p}=0.004)$ but not different from $\mathrm{T} 2 \mathrm{~b}$ patients $(\mathrm{p}=0.48)$. $\mathrm{LN}$ positive 


\begin{tabular}{|c|c|c|c|c|c|c|}
\hline $\begin{array}{l}\text { PPC } \leq \% 50 \\
\text { n (\%) }\end{array}$ & $\begin{array}{l}\text { PPC > \%50 } \\
\text { n (\%) }\end{array}$ & $\mathbf{p}$ & $\begin{array}{l}\text { TPC<\%50 } \\
\text { n (\%) }\end{array}$ & $\begin{array}{l}\text { TPC } \geq \% 50 \\
\text { n (\%) }\end{array}$ & $p$ & \\
\hline Mean Age & 68.3 & 66.3 & $<0.004$ & 68.2 & 65.5 & $<0.00$ \\
\hline \multicolumn{7}{|l|}{ iPSA Group } \\
\hline$\leq 10(\mathrm{ng} / \mathrm{ml})$ & $110(\% 53)$ & $54(\% 24)$ & & $132(\% 50)$ & $28(\% 19)$ & \\
\hline $10-20$ (ng/ml) & $51(\% 24)$ & 74 (\%33) & $<0.00$ & 73 (\%27) & 49 (\%33) & $<0.00$ \\
\hline$>20 \quad(\mathrm{ng} / \mathrm{ml})$ & 47 (\%23) & $97(\% 43)$ & & $62(\% 23)$ & $70(\% 48)$ & \\
\hline \multicolumn{7}{|l|}{ Gleason Score } \\
\hline$\leq 6$ & $115(\% 53.5)$ & $62(\% 27)$ & & $149(\% 53)$ & $20(\% 14)$ & \\
\hline 7 & 63 (\%29.3) & $69(\% 30)$ & $<0.00$ & 82 (\%29) & 43 (\%29) & $<0.00$ \\
\hline$\geq 8$ & 37 (\%17.2) & $98(\% 43)$ & & $49(\% 18)$ & 85 (\%57) & \\
\hline $\mathrm{PNI}(+)$ & $53(\% 25)$ & $135(\% 62)$ & $<0.00$ & 88 (\%32) & $104(\% 74)$ & $<0.00$ \\
\hline PNI (-) & $160(\% 75)$ & $83(\% 38)$ & & $186(\% 68)$ & 37 (\%26) & \\
\hline \multicolumn{7}{|l|}{ Clinical Stage } \\
\hline T1-T2a & $132(\% 61)$ & $80(\% 35)$ & & $168(\% 60)$ & $38(\% 26)$ & \\
\hline $\mathrm{T} 2 \mathrm{~b}$ & $18(\% 9)$ & $18(\% 8)$ & $<0.00$ & $19(\% 7)$ & $13(\% 9)$ & $<0.00$ \\
\hline T2c-T4 & $65(\% 30)$ & $128(\% 57)$ & & 93 (\%33) & $65(\% 65)$ & \\
\hline \multicolumn{7}{|l|}{ D'Amico Risk } \\
\hline Low & $56(\% 26)$ & $15(\% 6)$ & & $68(\% 24)$ & 4 (\%3) & \\
\hline Intermediate & 56 (\%26) & $32(\% 14)$ & $<0.00$ & 70 (\%25) & $12(\% 8)$ & $<0.00$ \\
\hline High & $103(\% 48)$ & $182(\% 80)$ & & $142(\% 51)$ & $131(\% 89)$ & \\
\hline ADT $<1$ year & $142(\% 70)$ & $89(\% 41)$ & $<0.00$ & $173(\% 65)$ & 53 (\%38) & \\
\hline ADT $\geq 1$ year & $62(\% 30)$ & $128(\% 59)$ & & $92(\% 35)$ & 87 (\%62) & $<0.00$ \\
\hline
\end{tabular}

patients had worse CSS than LN negative patients $(\mathrm{p}=0.008)$. GS, PSA, D'Amico risk groups, TPC, PPC and PNI were all significantly associated with CSS rates (Table 3 and Figure 1). Patients with GS $\geq 8$ had significantly poor survival than GS 7 ( $\mathrm{p}=$ $0.015)$ and $G S \leq 6$ patients $(p<0.001)$. Survival was worse in patients with GS 7 compared to GS $\leq$ 6 patients $(\mathrm{p}=0.08)$. CSS in patients with PSA $\leq 10$ $\mathrm{ng} / \mathrm{ml}$ was better than the subsequent PSA groups $(p=0.01$ and $p<0.001$, respectively). Patients with PSA $10-20 \mathrm{ng} / \mathrm{ml}$ had better CSS compared to patients with PSA > $20 \mathrm{ng} / \mathrm{ml}(\mathrm{p}=0.04)$. D'Amico high risk patients had worse CSS rates than low and intermediate risk patients (Table 3). Higher TPC and PPC and presence of PNI were all related to poor CSS (Figure 1).

\section{PSA Relapse Free Survival}

One hundred thirty five PSA relapses were reported. Five and 10 years PSA-RFS rates were $77 \%$ and 55\% and median PSA relapse free period was 54.5 months. We found a significant difference between T1a-T2a and T2c-T3b groups in favour of T1a-T2a group $(p=0.003)$. Five year PSA-RFS rates in the $\mathrm{LN}$ positive and $\mathrm{LN}$ negative patients were $52 \%$ and $78 \%$, respectively $(\mathrm{p}=0.001)$. The 5 and 10 year PSA-RFS rates in three GS groups were shown in Table 4. There was no significant difference in terms of PSA-RFS between GS $\leq 6$ and GS 7 groups $(\mathrm{p}=0.15)$. Patients with $\mathrm{GS} \geq 8$ had significantly worse PSA-RFS than patients with either GS $\leq 6(\mathrm{p}<0.001)$ or GS $7(\mathrm{p}=0.002)$.

PSA-RFS is affected from the increasing PSA levels. 5-10 year PSA-RFS rates in PSA $\leq 10 \mathrm{ng} /$ $\mathrm{ml}$, PSA $10-20 \mathrm{ng} / \mathrm{ml}$ and PSA $>20 \mathrm{ng} / \mathrm{ml}$ groups were; $88 \%$ and $74 \%, 79 \%$ and $46 \%$, and $62 \%$ and $40 \%$, respectively. PSA-RFS rate in the PSA $>20$ $\mathrm{ng} / \mathrm{ml}$ group was significantly worse compared to PSA $10-20 \mathrm{ng} / \mathrm{ml}$ group $(\mathrm{p}=0.007)$ and PSA $\leq 10$ $\mathrm{ng} / \mathrm{ml}$ group $(\mathrm{p}<0.001)$. 
International Journal of Hematology and Oncology
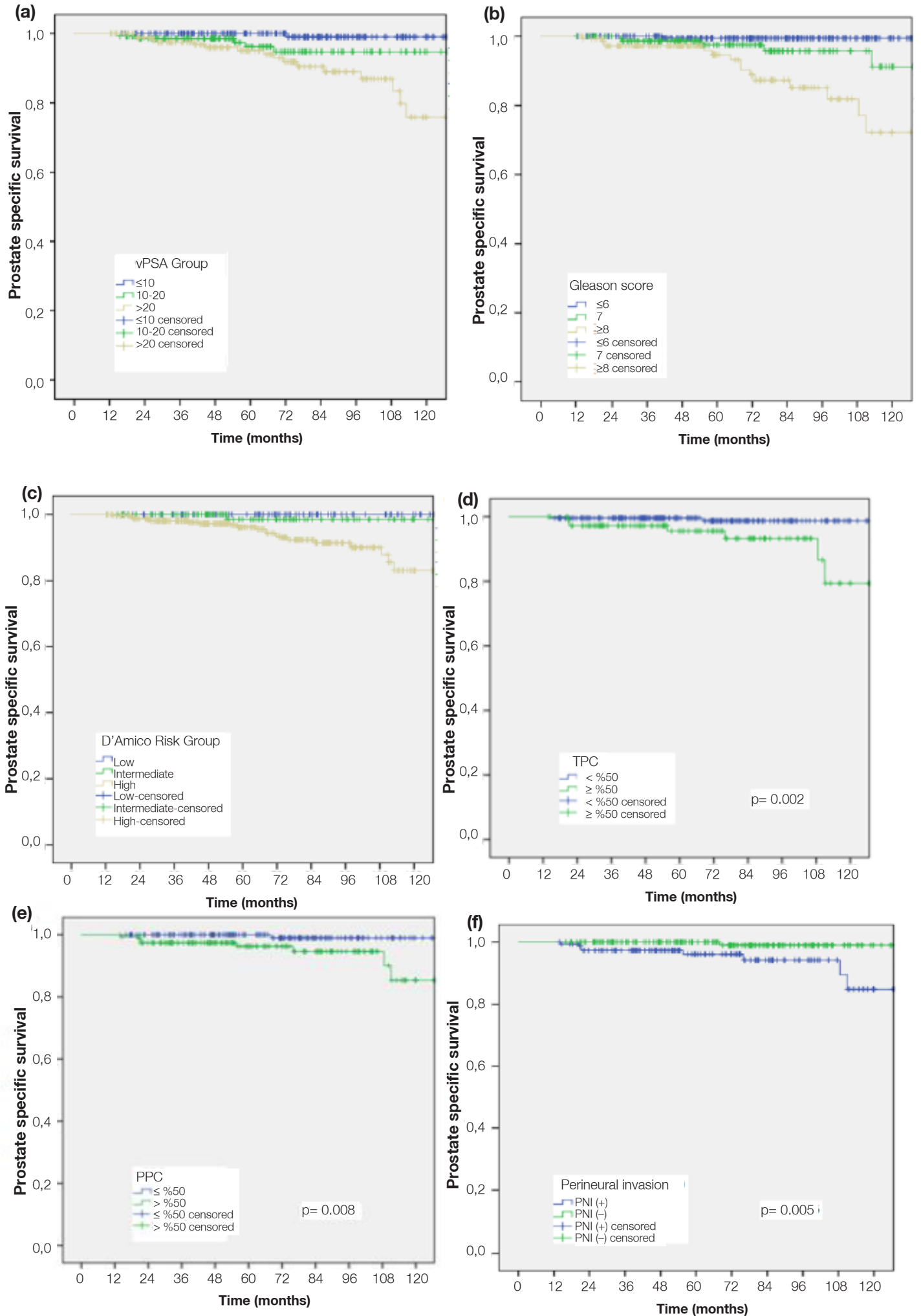

Figure 1. Prostate cancer specific survival curves according to (a) initial prostate specific antigen (vPSA), (b) Gleason score (GS), (c) D'Amico risk groups, (d) total percentage of cancer containing cores (TPC), (e) percent of positive cores (PPC), (f) perineural invasion (PNI) status. 
Five year PSA-RFS rates in the low, intermediate and high risk disease groups were 93\%, $77 \%$ and $72 \%$, respectively. Patients in the high risk disease group had worse PSA-RFS compared to low risk $(p<0.001)$ and intermediate risk groups $(p<0.001)$.

Five-10 year PSA-RFS rates were $60 \%$ and $42 \%$ in the $\mathrm{TPC} \geq 50 \%$ group and $86 \%$ and $68 \%$ in the TPC $<50 \%$ group ( $<<0.001) ; 65 \%$ and $44 \%$ in the PPC $>50 \%$ group and $89 \%$ and $85 \%$ in the $\mathrm{PPC} \leq 50 \%$ group, respectively $(\mathrm{p}<0.001)$. PNI status was also predictive in terms of PSA-RFS ( $\mathrm{p}=$ $0.005)$.

In the multivariate analysis, iPSA levels $(\mathrm{p}<$ $0.001)$, LN status $(\mathrm{p}=0.001)$, TPC $(\mathrm{p}=0.04)$ and PPC $(\mathrm{p}=0.05)$ were found to be significantly affecting the PSA-RFS. Additionally, patients with LN positive disease had 3.8 times increase in the rate of PSA relapse compared to LN negative patients. Compared to patients with PSA $\leq 10 \mathrm{ng} /$ $\mathrm{ml}$; PSA relapse rates were increased 2 times in patients with PSA $10-20 \mathrm{ng} / \mathrm{ml}$ and 3.5 times in patients with PSA $>20 \mathrm{ng} / \mathrm{ml}$.

\section{Distant Metastasis Free Survival}

There were 37 distant metastases. Fifty percent of the patients had no metastases until 65.9 months in their follow up. The patients with T2c-T3b had more distant metastases compared to T1a-T2a patients $(p=0.007)$. Five and 10 year DMFS rates in the $\mathrm{LN}$ positive and $\mathrm{LN}$ negative groups were $82 \%$ and $66.5 \%$ and $96 \%$ and $95 \%$, respectively $(\mathrm{p}<0.001)$.

Five and 10 year DMFS rates according to GS are shown in Table 4. Patients in GS $\geq 8$ group had significantly worse DMFS compared to patients in GS $7(\mathrm{p}=0.001)$ and $\mathrm{GS} \leq 6$ groups $(\mathrm{p}=0.001)$.

Patients with PSA $\leq 10 \mathrm{ng} / \mathrm{ml}$ had 5 and 10 year DMFS rates of $98 \%$ and $97 \%$; patients with PSA $10-20 \mathrm{ng} / \mathrm{ml}$ had 5 and 10 year DMFS rates of $95 \%$ and $90 \%(\mathrm{p}=0.05)$. Patients with PSA $>20 \mathrm{ng} / \mathrm{ml}$ had 5 and 10 years DMFS rates of $89 \%$ and $77 \%$, respectively. Thus, patients with PSA $>20 \mathrm{ng} / \mathrm{ml}$ had worse DMFS compared to patients with PSA $\leq$ $10 \mathrm{ng} / \mathrm{ml}(\mathrm{p}<0.001)$ and PSA $10-20 \mathrm{ng} / \mathrm{ml}(\mathrm{p}=0.05)$

Patients in the low and intermediate risk groups did not have significant difference in DMFS ( $\mathrm{p}=$
$0.15)$. However, patients in the high risk group had worse DMFS rates compared to intermediate risk $(\mathrm{p}=0.04)$ and low risk groups $(\mathrm{p}=0.004)$.

Five and 10 year DMFS in the TPC $\geq 50 \%$ group were $88 \%$ and $66 \%$ compared to $98 \%$ in the TPC < $50 \%$ group $(\mathrm{p}<0.001)$. Five-10 year DMFS in the PPC $>50 \%$ group were $90 \%-81 \%$ in compared to $98 \%$ in PPC $\leq 50 \%$ group $(\mathrm{p}<0.001)$. Patients with PNI had worse DMFS than PNI negative patients $(\mathrm{p}=0.03)$.

In the multivariate analysis, LN positivity $(\mathrm{p}=$ $0.001)$ and TPC $\geq \% 50(\mathrm{p}=0.05)$ were shown to increase the risk of distant metastasis. Patients with GS $\geq 8$ had significantly risk of distant metastasis compared to patients with $\mathrm{GS} \leq 6(\mathrm{p}=0.01)$.

\section{Androgen Deprivation Therapy}

Seventy nine percent of patients that used $\geq 1$ year ADT and $53 \%$ of the patients that used $<1$ year ADT were in the D'Amico high risk group. Although $44 \%$ and $47 \%$ of the patients that used long term ADT were the patients with GS $\geq 8$ and PSA> $20 \mathrm{ng} / \mathrm{ml}$; these rates were only $19 \%$ and $24 \%$ in < 1 year ADT used patients, respectively. Only $11 \%$ and $61 \%$ of the group used ADT for $\geq 2$ years and $\geq 1$ year respectively

In the whole group 5 and 10 years OS rates in patients that used ADT < 1 year were $99.5 \%$ and $\% 90.6$ compared to $94 \%$ and $90 \%$ in group of patients that used ADT $\geq 1$ year $(\mathrm{p}=0.03)$. In the subgroup of patients with $\mathrm{GS} \geq 8$, there was no significant difference between $<1$ years and $\geq 1$ years of ADT in terms of CSS ( $\mathrm{p}=0.3)$, PSA-RFS ( $\mathrm{p}=$ $0.15)$ and DMS $(p=0.4)$. However OS was better in patients with $<1$ year ADT (Figure 2) $(\mathrm{p}=0.01$ ). Five and 10 years OS rates were $100 \%$ and $53 \%$ in short term ADT used group; $94 \%$ and $66 \%$ in long term ADT used group.

In the high risk patients, 5 years OS $(\mathrm{p}=0.02)$, CSS $(\mathrm{p}=0.05)$, PSA-RFS $(\mathrm{p}=0.01)$ and DMFS $(\mathrm{p}=$ 0.07 ) rates were better in patients that used ADT< 1 years. 


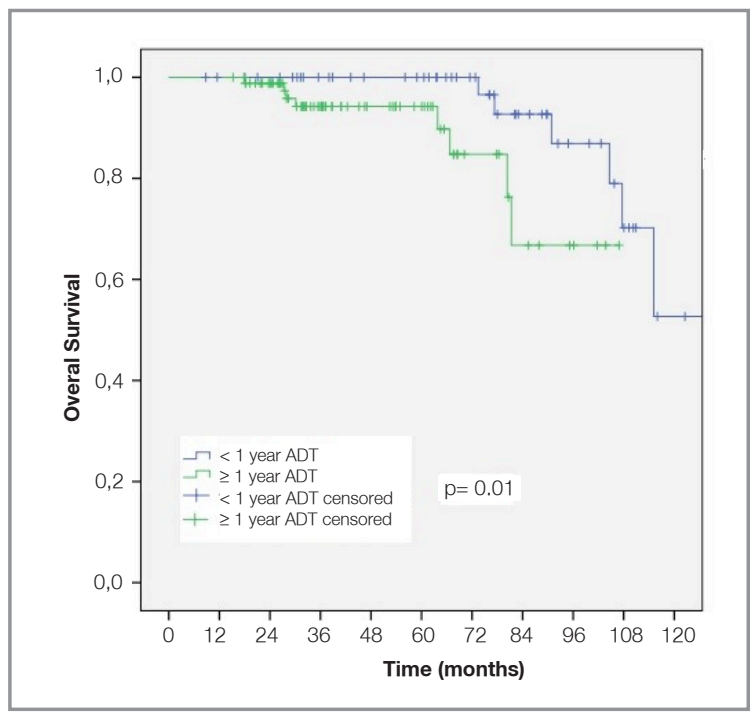

Figure 2. Overall survival in Gleason 8-10 patients according to the ADT duration.

\section{Toxicity}

RT related acute toxicities were evaluated using RTOG Acute Radiation Morbidity criteria and late toxicities were evaluated using RTOG/EORTC Late Radiation Morbidity scoring schema. ${ }^{7}$ The data about toxicity of gastrointestinal and genitourinary systems were available $83 \%$ and $85 \%$ of the patients, respectively. The treatment was well tolerated with few grade 3 toxicities. Acute grade 3 genitourinary and gastrointestinal toxicities were reported in $1.4 \%$ and $1.7 \%$ of cases. Twenty five late grade 3 gastrointestinal toxicities were reported $(5 \%)$. These patients had gastrointestinal (GIS) haemorrhage that was required argon laser therapy. Only 1 patient had faecal incontinence as grade 3 toxicity. Twenty eight (6\%) patients had RTOG grade 3 genitourinary (GUS) toxicities due to radiation stricture that needed minimally invasive procedures (urethral dilation, catheterization, transurethral resection of prostate or cystoscopy). Twelve of those 28 patients had also urinary incontinence. Two patients had both GIS and GUS Grade 3 toxicity. There was no grade 4 GIS or GUS toxicity.

\section{DISCUSSION}

The classic prognostic factors for prostate cancer are clinical TNM stage, histological grade, GS and iPSA. ${ }^{8}$ These parameters are used to categorize patients into some risk groups and decide the appropriate treatment. In this study we prospectively evaluated the treatment results of our patients with prostate cancer in terms of OS, CSS, PSA-RFS and DMFS in each classical risk status and also we studied the other factors like TPC, PPC and PNI that have not been routinely used in predictive algorithm.

It was shown that higher GS is associated with greater likelihood of having non-organ confined disease, as well as a worse outcome after treatment of localized disease. ${ }^{9}$ In our study, the patients with GS $\geq 8$ had tendency to be in clinical T2c-T3b stage compared to be in clinical T1-2a stage. In GS $\geq 8$ group, the percentage of the patients with PSA $>20 \mathrm{ng} / \mathrm{ml}$ and with PSA $\leq 10 \mathrm{ng} / \mathrm{ml}$ were $45 \%$ and $23 \%$, respectively. These patients had decreased rate of OS, CSS, PSA-RFS and DMFS than GS $\leq 6$ and GS 7 patients in our study.

In LN positive patients, there is evidence to support attempts to control primary tumor ${ }^{10}$ and a systemic review concluded that in $\mathrm{T} 3$ and/or $\mathrm{LN}$ positive diseases the local therapy is an essential part of the optimal treatment. ${ }^{11}$ When RT is combined with ADT in LN positive patients, retrospective data suggest excellent biochemical control rates at 5 and 10 years. ${ }^{12}$ In RTOG $85-32$ trial, LN positive patients that received whole pelvic RT (WPRT) with combined hormonal treatment, had better biochemical control rates at 5 and 9 years compared to WPRT only; $54 \%$ and $10 \%$ versus $33 \%$ and $4 \%$, respectively. In our trial, although all of the outcomes were worse in $\mathrm{LN}$ positive patients compared to LN negative counterparts $(p=0.001)$, there were only 5 deaths because of prostate cancer in LN positive patients. This may be explained by the pelvic RT, long ADT duration and short follow up time in this group of LN positive patients. Twenty seven of $29 \mathrm{LN}$ positive patients in our study received ADT of $\geq 1$ year. Observational series of external RT for $\mathrm{LN}$ positive prostate cancer 
patients have suggested favourable outcomes after local therapy, with 10 -year CSS rates in the range of $60 \%$ and $85 \% .^{13,14}$ In our study due to low numbers of LN positive patients, we only report 5 year CSS rates of $80 \%$. However we know that more patients and more follow-up time are required to compare our results with the other trials.

After radical prostatectomy (RP) or RT, there is limited data supporting the utility of biopsy surrogates of prostate volume like PPC and TPC for prediction of prognosis. ${ }^{15}$ The relation between PPC and biochemical relapse free survival (BFS) was explored after $\mathrm{ADT}^{16}, \mathrm{RP}^{16-18}$, after $\mathrm{WPRT}^{4,19,20}$ and brachyterapy. ${ }^{21-24}$ Although the prognostic significance of PPC couldn't be demonstrated in some studies $^{22}$, Yushen et al reported the prognostic value of PPC in intermediate and high risk patients with regard to CSS, BFS and DMFS. ${ }^{25}$ Freedland et al reported that PPC in biopsy was an independent predictor of biochemical relapse and adverse pathological findings like higher T stage, higher GS and positive surgical margin following RP. ${ }^{26}$ Briganti et al reported that PPC has a predictive value for estimating the lymphatic invasion in addition to PSA, clinical T stage and GS. ${ }^{27}$ In Huang's study, higher PPC was associated with younger age, unfavourable risk factors like higher T stage, GS and PSA, presence of PNI and more aggressive treatment. Association of PPC with distant metastases (DM) and correlation of PPC with OS were reported in high risk patients. ${ }^{28}$

More quantitative assessments of biopsy tumor volume, such as percentage of tumor volume (PCV) have been studied in the context of RP, brachytherapy, androgen deprivation therapy, External RT or combined treatments. These studies all suggested that the PCV is a more discriminating prognostic variable than the PPC. ${ }^{29}$

In our study, higher PPC (>50\%) and higher TPC $(\geq 50 \%)$ were all correlated with higher GS, PSA, $\mathrm{T}$ stage, prolonged ADT and presence of PNI ( $\mathrm{p}<$ 0.00 ). Also we found that younger patients had tendency to have higher PPC and higher TPC. We could not find any relation between the age of patients and PNI. On univariate analysis we found a negative correlation between the extent of cores (PPC, TPC and PNI) and CCS, BFS and DMFS.
On multivariate analysis, we evaluated PPC, TPC, PNI, GS, PSA, T stage, risk groups and we obtained significant association between PSA-RFS and PPC $(\mathrm{p}=0.025)$ and $\mathrm{PSA}>20 \mathrm{ng} / \mathrm{ml}(\mathrm{p}=0.002)$ patients. When we exclude PPC from the analysis, TPC also significantly affects the PSA-RFS ( $\mathrm{p}<$ 0.001 ). We found that $\mathrm{TPC} \geq 50 \%$ patients had higher GS, PSA, T stage, PNI positivity and are in high risk group compared to PPC $>\% 50$ patients. But why couldn't we find the predictive value of TPC when they were both calculated in same Cox analysis? We think that although the patients with $\mathrm{TPC} \geq 50 \%$ had poorer factors but could not be able to indicate significance in Cox analysis, the predictive value of PPC should have been more valuable. This is contrary to Vance's study ${ }^{29}$ where they reported TPC as a prognostic factor for CSS, PSA-RFS and DMFS. However in their study PPC failed to show an advantage in multivariate analysis. In that study they evaluated the TPC volumes in four quartiles including $<2.5 \%,<10 \%,<25 \%$ and $\geq 25 \%$ TPC. They reported that the NCCN high risk patients with TPC $<\% 25$ had better clinical outcomes than the high risk group with TPC $\geq 25 \%$. Similarly the patients with Gleason score 8-10 and high TPC had worse outcomes than the patients with Gleason score 8-10 and low TPC. In our study we grouped TPC into TPC $<50 \%$ and $\mathrm{TPC} \geq 50 \%$. Although we found the similar effect of TPC, our large ranges of $50 \%$ were probably less reliable to make more precise prognostic classification in comparison to Vance's study.

In RTOG 92-02 randomized trial that studied optimal duration of ADT, patients received 4 months of goserelin acetate and flutamid 2 months before and after RT. RT was applied to the prostate and pelvic LNs and then prostate was boosted to a total dose of 65-70 Gy. Patients then were randomized to no further therapy or 2 years goserelin acetate. Ten years of updated results of the study showed that CSS, PSA-RFS, local control and DMFS were all in favour of long term ADT. They also found OS advantage specific to GS 8-10 group that used long term $\mathrm{ADT} .{ }^{30}$ In EORTC phase III trial RT versus RT plus ADT was compared. External RT was delivered as in RTOG 92-02 study and hormonal therapy consisted of goserelin acetate for 3 years beginning on the first day of RT. In the updated 
results OS, PSA-RFS and DMFS were statistically better in the combined therapy than only RT arm. ${ }^{31}$ These trials showed that the addition of ADT to conventional dose RT resulted in clear improvement in treatment outcomes like OS, BFS and DMFS.

It is also known that a BED of $\geq 150$ Gy resulted in a $92 \%$ freedom from biochemical failure versus $62 \%$ with $\mathrm{BED}<150 \mathrm{~Gy}$. The role of ADT with optimal dose escalation should be defined. In our study, high risk patients that used ADT $<1$ years had better 5 years OS $(\mathrm{p}=0.02), \mathrm{CSS}(\mathrm{p}=0.05)$, PSA-RFS $(p=0.01)$ and DMFS $(p=0.07)$. Forty-four percent of patients using long term ADT were the patients with Gleason score 8-10. When we compared our study with RTOG and EORTC trials, the duration of hormonal therapy might be shorter and also only $6 \%$ of the patients had pelvic RT. Our RT dose was higher than their conventional RT doses. Stock et al reported excellent results with 9-12 months of ADT combined with high doses of external RT plus brachytherapy. ${ }^{32}$ The role of 6 months of ADT with high doses of RT is being investigated in RTOG 0815 randomized trial. ${ }^{33}$

Radiation induced proctitis includes symptoms like rectal pain, diarrhea, rectal bleeding, increased frequency of movements and urgency. The frequency of proctitis after 3D CRT of localized prostate cancer is $5-20 \%{ }^{34,35}$ In a multicenter trial where 450 patients were treated by 3D CRT, the rate of Grade 2 and Grade 3 late rectal side effects was reported to be $21 \%$ and $3 \%$, respectively. ${ }^{36}$ Zelefsky reported Grade 3 proctitis which required blood transfusion or laser coagulation only in 15 patients (1\%). It should be considered that they used either intensity modulated radiotherapy (IMRT) or 3DCRT in their trial and they stated a significant decline in the incidence of Grade $\geq 2$ GI toxicities with IMRT. ${ }^{37}$ In our study $5 \%$ of the patients had Grade 3 late rectal toxicity which is higher than Zelefskys's trial. The possible reason of high Grade 3 toxicity in our study may be the RT modality as we treated all patients with 3DCRT only. The other treatment related toxicity is faecal incontinence that is thought to be caused by radiation exposure of the ano-rectum. The precise mechanism is not known and the relationship between dose volume parameters and the severity of faecal incontinence symptoms has not been fully established. ${ }^{38}$ AIRO PROS 0102 trial reported a rate of $10.9 \%$ Grade $\geq 1$ faecal incontinence. ${ }^{39}$ In our study, faecal incontinence was reported only in one patient. This low rate may arise from the missing data or insufficient feedback because of socio-cultural level of patients.

In this study we reported out treatment results in the 3DCRT era. 3DCRT and ADT combination is an effective treatment modality with acceptable toxicities in patients with prostate cancer. However it is known that IMRT has the ability to deliver higher radiation doses to the target while sparing the normal adjacent structures. Thus we now treat prostate cancer patients with IMRT to a total dose of 76 Gy. Additionally, it is clear that PPC, TPC and PNI are independently important as prognostic markers for prostate cancer. These factors should also be incorporated to formal risk group classification to select the appropriate treatment for patients. Using smaller cut off points for TPC and PPC may increase the sensibility of these markers in assessing the prognosis.

\section{REFERENCES}

1. Pilepich MV, Winter K, John MJ, et al. Phase III radiation therapy oncology group (RTOG) trial 86-10 of androgen deprivation adjuvant to definitive radiotherapy in locally advanced carcinoma of the prostate. Int J Radiat Oncol Biol Phys 50: 1243-1252, 2001.

2. Laverdiere J, Nabid A, De Bedoya LD, et al. The efficacy and sequencing of a short course of androgen suppression on freedom from biochemical failure when administered with radiation therapy for T2-T3 prostate cancer. J Urology 2004, 171: 1137-1140, 2004.

3. Denham JW, Steigler A, Lamb DS, et al. Short-term neoadjuvant androgen deprivation and radiotherapy for locally advanced prostate cancer: 10-year data from the TROG 96.01 randomised trial. Lancet Oncol 12: 451-459, 2011.

4. D'Amico AV, Schultz D, Silver B, et al. The clinical utility of the percent of positive prostate biopsies in predicting biochemical outcome following external-beam radiation therapy for patients with clinically localized prostate cancer. Int J Radiat Oncol Biol Phys 49: 679-684, 2001.

5. Bastacky SI, Walsh PC, Epstein Jl. Relationship between perineural tumor invasion on needle biopsy and radical prostatectomy capsular penetration in clinical stage B adenocarcinoma of the prostate. Am J Surg Pathol 17: 336-341, 1993. 
6. D'Amico AV, Whittington R, Malkowicz SB, et al. Biochemical outcome after radical prostatectomy, external beam radiation therapy, or interstitial radiation therapy for clinically localized prostate cancer. JAMA 280: 969-974, 1998.

7. Cox JD, Stetz J, Pajak TF. Toxicity criteria of the Radiation Therapy Oncology Group (RTOG) and the European Organization for Research and Treatment of Cancer (EORTC). Int $\mathrm{J}$ Radiat Oncol Biol Phys 31: 1341-1346, 1995.

8. Dirix $\mathrm{P}$, Joniau $\mathrm{S}$, Van den Bergh $\mathrm{L}$, et al. The role of elective pelvic radiotherapy in clinically node-negative prostate cancer: a systematic review. Radiother Oncol 110: 45-54, 2014.

9. Ellis CL, Partin AW, Han M, Epstein Jl. Adenocarcinoma of the prostate with Gleason score 9-10 on core biopsy: correlation with findings at radical prostatectomy and prognosis. J Urol 190: 2068-2073, 2013.

10. Messing EM, Manola J, Yao J, et al. Immediate versus deferred androgen deprivation treatment in patients with nodepositive prostate cancer after radical prostatectomy and pelvic lymphadenectomy. Lancet Oncol 7: 472-479, 2006.

11. Verhagen PC, Schroder FH, Collette L, Bangma CH. Does local treatment of the prostate in advanced and/or lymph node metastatic disease improve efficacy of androgen-deprivation therapy? A systematic review. Eur Urol 58: 261-269, 2010.

12. Crehange G, Chen CP, Hsu CC, et al. Management of prostate cancer patients with lymph node involvement: a rapidly evolving paradigm. Cancer treat rev 38: 956-967, 2012.

13. Pilepich MV, Winter K, Lawton CA, et al. Androgen suppression adjuvant to definitive radiotherapy in prostate carcinoma-long-term results of phase III RTOG 85-31. Int J Radiat Oncol Biol Phys 61: 1285-1290, 2005.

14. Robnett TJ, Whittington R, Malkowicz SB, et al. Long-term use of combined radiation therapy and hormonal therapy in the management of stage D1 prostate cancer. Int J Radiat Oncol Biol Phys 2002, 53: 1146-1151.

15. Epstein Jl. Prognostic significance of tumor volume in radical prostatectomy and needle biopsy specimens. J Urol 186: 790-797, 2011.

16. Normand G, Celhay O, Briffaux R, et al. Percentage of positive biopsy cores at the onset of hormone therapy for prostate cancer: prognostic significance. Urol Int 83: 160-165, 2009.

17. D'Amico AV, Whittington R, Malkowicz SB, et al. Clinical utility of the percentage of positive prostate biopsies in defining biochemical outcome after radical prostatectomy for patients with clinically localized prostate cancer. J Clin Oncol 18: 1164-1172, 2000.

18. Freedland SJ, Aronson WJ, Terris MK, et al. The percentage of prostate needle biopsy cores with carcinoma from the more involved side of the biopsy as a predictor of prostate specific antigen recurrence after radical prostatectomy: results from the Shared Equal Access Regional Cancer Hospital (SEARCH) database. Cancer 98: 2344-2350, 2003.
19. Spalding AC, Daignault S, Sandler HM, et al. Percent positive biopsy cores as a prognostic factor for prostate cancer treated with external beam radiation. Urology 69: 936-940, 2007.

20. Wong WW, Schild SE, Vora SA, Halyard MY. Association of percent positive prostate biopsies and perineural invasion with biochemical outcome after external beam radiotherapy for localized prostate cancer. Int J Radiat Oncol Biol Phys 60: 24-29, 2004.

21. Kestin LL, Goldstein NS, Vicini FA, Martinez AA. Percentage of positive biopsy cores as predictor of clinical outcome in prostate cancer treated with radiotherapy. J Urol 168: 19941999, 2002.

22. Pe ML, Trabulsi EJ, Kedika R, et al. Effect of percentage of positive prostate biopsy cores on biochemical outcome in low-risk PCa treated with brachytherapy or 3D-CRT. Urology 73: 1328-1334, 2009

23. Merrick GS, Butler WM, Galbreath RW, et al. Relationship between percent positive biopsies and biochemical outcome after permanent interstitial brachytherapy for clinically organconfined carcinoma of the prostate gland. Int J Radiat Oncol Biol Phys 52: 664-673, 2002.

24. Rossi PJ, Clark PE, Papagikos MA, et al. Percentage of positive biopsies associated with freedom from biochemical recurrence after low-dose-rate prostate brachytherapy alone for clinically localized prostate cancer. Urology 67: 349-353, 2006.

25. Qian $\mathrm{Y}$, Feng FY, Halverson $\mathrm{S}$, et al. The percent of positive biopsy cores improves prediction of prostate cancer-specific death in patients treated with dose-escalated radiotherapy. Int J Radiat Oncol Biol Phys 81: e135-142, 2011.

26. Freedland SJ, Aronson WJ, Terris MK, et al. Percent of prostate needle biopsy cores with cancer is significant independent predictor of prostate specific antigen recurrence following radical prostatectomy: results from SEARCH database. J Urol 2003, 169: 2136-2141.

27. Briganti A, Karakiewicz PI, Chun FK, et al. Percentage of positive biopsy cores can improve the ability to predict lymph node invasion in patients undergoing radical prostatectomy and extended pelvic lymph node dissection. Eur Urol 51: 1573-1581, 2007.

28. Huang J, Vicini FA, Williams SG, et al. Percentage of positive biopsy cores: a better risk stratification model for prostate cancer? Int J Radiat Oncol Biol Phys 83: 1141-1148, 2012.

29. Vance SM, Stenmark MH, Blas K, et al. Percentage of cancer volume in biopsy cores is prognostic for prostate cancer death and overall survival in patients treated with dose-escalated external beam radiotherapy. Int J Radiat Oncol Biol Phys 83: 940-946, 2012.

30. Horwitz EM, Bae K, Hanks GE, et al. Ten-year follow-up of radiation therapy oncology group protocol 92-02: a phase III trial of the duration of elective androgen deprivation in locally advanced prostate cancer. J Clin Oncol 26: 2497-2504, 2008. 
31. Bolla M, Van Tienhoven G, Warde P, et al. External irradiation with or without long-term androgen suppression for prostate cancer with high metastatic risk: 10-year results of an EORTC randomised study. Lancet Oncol 11: 1066-1073, 2010.

32. Ko EC, Liu JT, Stone NN, Stock RG. Association of early PSA failure time with increased distant metastasis and decreased survival in prostate brachytherapy patients. Radiother Oncol 110: 261-267, 2014.

33. Cheney MD, Chen MH, Zhang D, et al. Greatest percentage of involved core length and the risk of death from prostate cancer in men with highest Gleason score $>/=7$. Clin Genitourin Cancer 12: 234-240, 2014.

34. Nichol A, Chung P, Lockwood G, et al. A phase II study of localized prostate cancer treated to 75.6 Gy with 3D conformal radiotherapy. Radiother Oncol 76: 11-17, 2005.

35. Rancati T, Fiorino C, Gagliardi G, et al. Fitting late rectal bleeding data using different NTCP models: results from an Italian multi-centric study (AIROPROS0101). Radiotherapy and oncology : journal of the European Society for Therapeutic Radiology and Oncology 73: 21-32, 2004.

36. Goldner G, Tomicek B, Becker G, et al. Proctitis after external-beam radiotherapy for prostate cancer classified by Vienna Rectoscopy Score and correlated with EORTC/RTOG score for late rectal toxicity: results of a prospective multicenter study of 166 patients. Int J Radiat Oncol Biol Phys 67: 78-83, 2007.

37. Zelefsky MJ, Levin EJ, Hunt M, et al. Incidence of late rectal and urinary toxicities after three-dimensional conformal radiotherapy and intensity-modulated radiotherapy for localized prostate cancer. Int J Radiat Oncol Biol Phys 70: 1124-1129, 2008.

38. Maeda Y, Hoyer M, Lundby L, Norton C. Faecal incontinence following radiotherapy for prostate cancer: a systematic review. Radiother Oncol 98: 145-153, 2011.

39. Tomatis S, Rancati T, Fiorino C, et al. Late rectal bleeding after 3D-CRT for prostate cancer: development of a neuralnetwork-based predictive model. Phys Med Biol 57: 13991412, 2012

\section{Correspondence}

Dr. Fadıl AKYOL

Hacettepe Üniversitesi Tıp Fakültesi

Radyasyon Onkolojisi Anabilim Dalı

06100, Sihhiye, ANKARA / TURKEY

Tel: (+90-312) 3052900

e-mail: hakyol@hacettepe.edu.tr 